\title{
High Temperature Electrochemical Separation of Carbon Dioxide Using Molten Carbonate
}

\author{
Hidekazu KASAI*, Takahiro MATSUO, Minoru HosaKA, Naobumi MoToHiRA, \\ Nobuyuki $\mathrm{KAMIYA}^{\dagger}$ and Ken-ichiro OTA ${ }^{\dagger}$
}

Received December 26, 1997 ; Accepted March 24, 1998

\begin{abstract}
The electrochemical separation and concentration of $\mathrm{CO}_{2}$ at high temperature $(923 \mathrm{~K})$ were studied using molten carbonate as the electrolyte. An electrolysis system was examined in the present study since a molten carbonate fuel cell had already demonstrated the concentration of $\mathrm{CO}_{2}$. Maximum concentration of $\mathrm{CO}_{2}$ after electrolysis using molten carbonate was $67 \%$, as determined by electrolysis using $\mathrm{Li} / \mathrm{K}$ molten carbonate and lithiated $\mathrm{NiO}$ as the cathode and anode, respectively. The cell voltage was $220 \mathrm{mV}$ at a current density of $100 \mathrm{~mA} / \mathrm{cm}^{2}$. These results show that the separation and concentration of $\mathrm{CO}_{2}$ by electrolysis proceed smoothly and theoretically. This method is expected to be applicable to $\mathrm{CO}_{2}$ and $\mathrm{O}_{2}$ recovery processes.
\end{abstract}

\section{INTRODUCTION}

\subsection{General}

Recently, it had been pointed out that $\mathrm{CO}_{2}$ gas contributes significantly to the green house effect. To recover or store $\mathrm{CO}_{2}$ effectively, it should be separated from other gases and concentrated. Various methods are available for this. Absorption of $\mathrm{CO}_{2}$ on a solvent ${ }^{1,2)}$, adsorption by solids, ${ }^{3)}$ into separation through use of an membrane, ${ }^{4)}$ and distillation at low temperature are methods presently in use. Most of such methods are Department of Fuel Cell Development Ishikawajima -Harima Heavy Industry Co., Ltd. (1-15, Toyosu,3chome, Koto-Ku, Tokyo 135-8732, Japan)

'Department of Energy Engineering, Yokohama National University(79-5 Tokiwadai, Hodogaya-ku, Yokohama 240-8501, Japan)

Key Words: $\mathrm{CO}_{2}$ separation, $\mathrm{CO}_{2}$ concentration, Molten carbonate, Electrolysis conducted at room temperature or low temperature. However, the high temperature separation seems to be more suitable for combustion exhaust gases than low temperature methods.

\subsection{Separation of $\mathrm{CO}_{2}$ using molten carbonate}

Molten alkaline carbonates or their mixtures, stable above $770 \mathrm{~K}$, are available to the electrolytes of high temperature electrochemical separation systems. In this system, the diffusion species in the electrolytes is carbonate ion, so that $\mathrm{CO}_{2}$ and $\mathrm{O}_{2}$ move from the cathode to anode selectively. Molten carbonate fuel cells (MCFC) seem to be useful owing to high energy conversion efficiency and are applicable to $\mathrm{CO}_{2}$ separation and concentration. Figure 1 shows the mechanism of $\mathrm{CO}_{2}$ concentration in MCFC. Gas analyses at the inlet and outlet of MCFC showed that $\mathrm{CO}_{2}$ in 
the cathode inlet gas was concentrated at the site of the anode outlet. ${ }^{3)}$ The concentration of $\mathrm{CO}_{2}$ has been studied by Weaver ${ }^{4)}$ using MCFC.

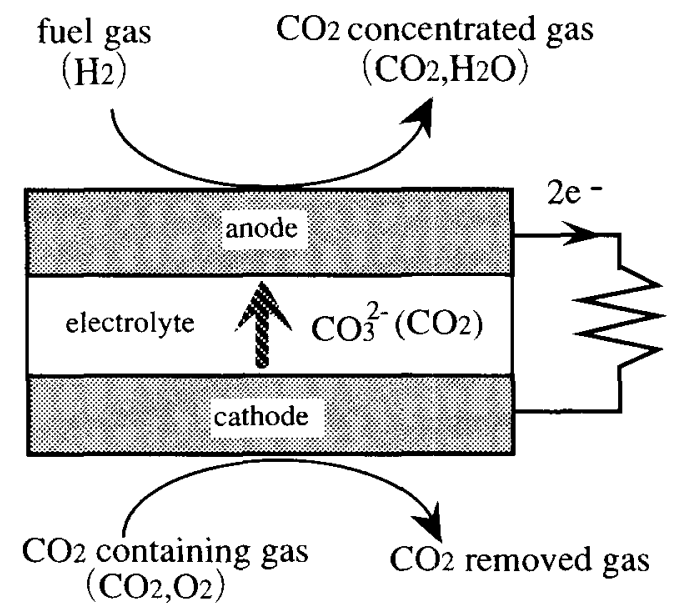

Fig. 1 Schematic drawing of $\mathrm{CO}_{2}$ separation using MCFC.

And the introduction of MCFC to power plants was also studied by Miyauchis). Separation is also possible in other process using molten carbonate as the electrolyte.

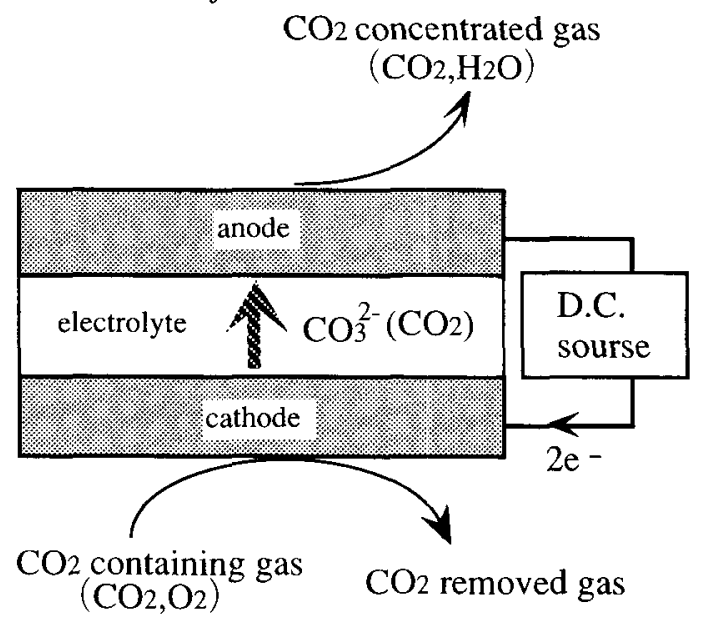

Fig. 2 Schematic drawing of $\mathrm{CO}_{2}$ separation using molten carbonate electrolytic cell.
In this case, electrical energy is required for electrolysis. This system is shown schematically in Fig. 2. Electrode reactions are as follows,

$$
\begin{aligned}
& \text { Cathode }: \mathrm{CO}_{2}+0.5 \mathrm{O}_{2}+2 \mathrm{e}^{-} \rightarrow \mathrm{CO}_{3}^{2-} \\
& \text { Anode }: \mathrm{CO}_{3}{ }^{2-} \rightarrow \mathrm{CO}_{2}+0.5 \mathrm{O}_{2}+2 \mathrm{e}^{-}
\end{aligned}
$$

The reaction (2) is the reverse of (1). Raw gas is introduced into the cathode and carbonate ions are formed. Carbonate ions move from the cathode to the anode. $\mathrm{CO}_{2}$ and $\mathrm{O}_{2}$ are produced by the decomposition of carbonate ions at the anode with a ratio of $2: 1$. Therefore the concentration of $\mathrm{CO}_{2}$ at the outlet is limited to $67 \%$. And $33 \% \mathrm{O}_{2}$ is obtained theoretically, that means the concentration of $\mathrm{O}_{2}$ is also increased in this process.

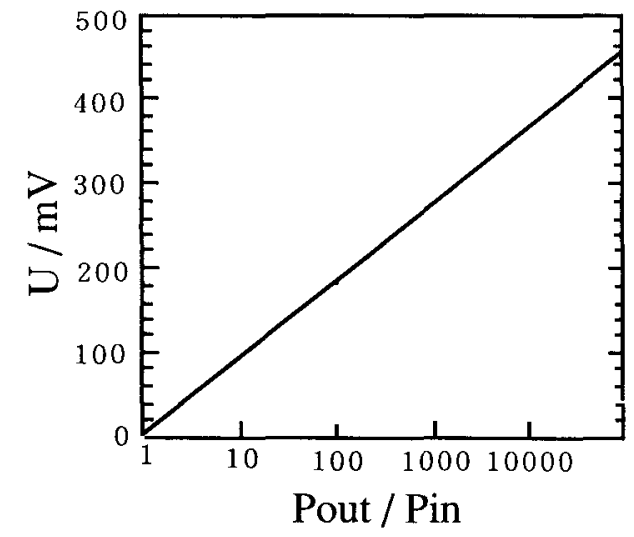

Fig.3 Theoretical voltage for the $\mathrm{CO}_{2}$ separating in case of the same $\mathrm{O}_{2}$ pressure between cathode and anode at $923 \mathrm{~K}$.

The theoretical potential difference Ur for reactions (1) and (2) is expressed as follows,

$$
\mathrm{Ur}=(\mathrm{RT} / 2 \mathrm{~F}) \ln \left(\mathrm{PcO}_{2(\mathrm{a})} \mathrm{Po}_{2(\mathrm{a})}{ }^{0.5} / \mathrm{Pco}_{2(\mathrm{c})} \mathrm{Po}_{2(c)}{ }^{0.5)}\right.
$$




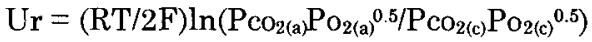

where (a) and (c) indicate the anode and cathode, respectively. Figure 3 shows the theoretical potential difference necessary for $\mathrm{CO}_{2}$ separation and concentration at $923 \mathrm{~K}$ when oxygen pressure is the same at the cathode and anode. Only $0.09 \mathrm{~V}$ is required for 10 times concentration of $\mathrm{CO}_{2}$. In this process, the overpotential arising from electrode kinetics and resistance of the electrolytic cell are key factors for the practical application. Then we attempted to confirm the concentration of $\mathrm{CO}_{2}$ in this study.

\section{EXPERIMENTAL}

All components of the electrolyticcell are shown in Fig. 4. SUS310S was used for exterior material and the current collector was SUS316L. The electrolytic matrix was $\mathrm{LiAlO}_{2}$ and the electrolyte, a $70 / 30$ carbonate mixture of $\mathrm{Li}_{2} \mathrm{CO}_{3}$ and $\mathrm{K}_{2} \mathrm{CO}_{3}$ near the eutectic point.

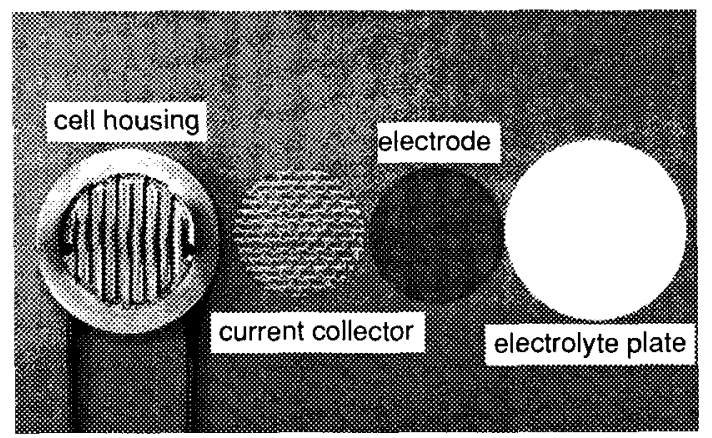

Fig.4 Electrolytic cell components.

The electrolyte plates and electrodes were formed by tapecasting. Both electrodes consist of porous $\mathrm{NiO}$ that oxidized and lithiated with carbonate. Assembled cell are shown in Fig. 5. These components specifications are described in Table 1. The experimental system for $\mathrm{CO}_{2}$ separation is presented in Fig. 6.

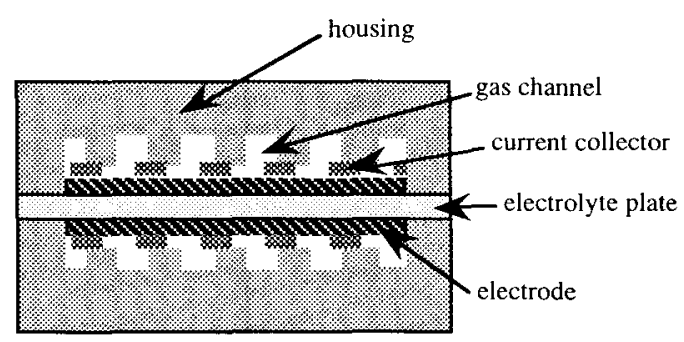

Fig.5 Electrolytic cell for $\mathrm{CO} 2$ separation.

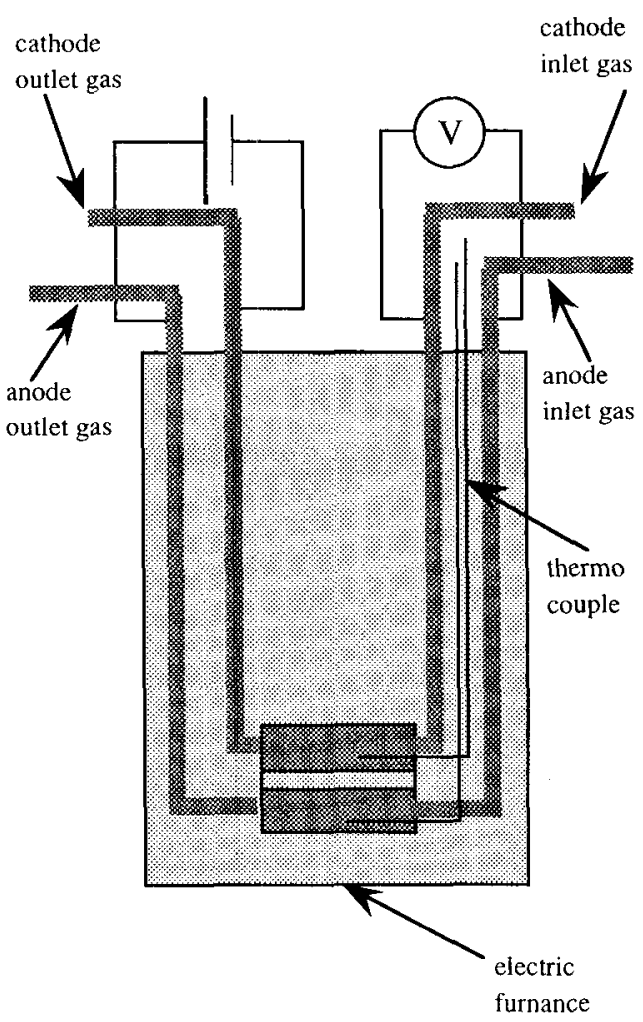

Fig. $6 \mathrm{CO}_{2}$ separation system.

The electrolytic cell was placed in an electric furnace for heating. Cell temperature was measured by chromel- 
alumel thermocouples inserted into the cell housing. Gas supply tubes were used for parts of circuit for measurement of cell voltage and current during $\mathrm{CO}_{2}$ separation.

Table 1 Cell component specifications.

\begin{tabular}{|c|c|c|c|c|}
\hline & $\begin{array}{c}\text { Thickness } \\
\text { (mm) }\end{array}$ & $\begin{array}{c}\text { Diameter } \\
(\mathrm{mm})\end{array}$ & $\begin{array}{c}\text { Prosity } \\
(\%)\end{array}$ & Marerial \\
\hline Cathode & 0.8 & 40 & 57 & $\mathrm{Ni}$ \\
\hline Anode & & & \multicolumn{2}{|c|}{ (in situ $\mathrm{NiO}$ ) } \\
\hline Electrolyteplate & 1.0 & 54 & 58 & $\mathrm{LiAlO}_{2}$ \\
\hline & & & \multicolumn{2}{|c|}{$\mathrm{Li}_{2} \mathrm{CO}_{3} / \mathrm{K}_{2} \mathrm{CO}_{3}=70 / 30$} \\
\hline
\end{tabular}

Cell voltage was measured and recorded by a data-logger (ADVANTEST R7326B). The gas composition was determined by a gas chromatograph (SHIMAZU GC-8A) and cell resistance was measured by $A C 4$ probes provided with a milliohm-meter (HEWLETT PACKARD $4328 \mathrm{~A}$ ). The gas flow rate was measured by a film flow meter (STEC SF-1100).

Table 2 Electrolytic cell operating cndition.
Temperature

Pressure

Cathode gas flow rate (inlet)

Anode gas flow rate (inlet)

Current density
$923 \mathrm{~K}$

$$
\begin{gathered}
1 \mathrm{~atm} \\
175 \mathrm{~cm}^{3} / \mathrm{min} \\
0 \mathrm{~cm}^{3} / \mathrm{min} \\
0 \sim 150 \mathrm{~mA} / \mathrm{cm}^{2}
\end{gathered}
$$

Cell operating conditions are indicated in Table 2. Electrolysis was conducted at $150 \mathrm{~mA} / \mathrm{cm}^{2}$ for cathode inlet gas of $10.0 \% \mathrm{CO}_{2}$ and $\mathrm{O}_{2}$ of $19.0 \%$. This concentration of $\mathrm{CO}_{2}$ is closed to the value of the exhaust gas from electric power station.

\section{RESULTS AND DISCUSSION}

During electrolysis, gas composition of anode outlet is shown in Table 3 .

Table 3 Gas composition.

(\%)

\begin{tabular}{lccc} 
Sample position & $\mathrm{O}_{2}$ & $\mathrm{~N}_{2}$ & $\mathrm{CO}_{2}$ \\
\hline Cathode inlet & 19.0 & 71.0 & 10.0 \\
& & & \\
Anode outlet & 33.3 & 0.0 & 66.7 \\
\hline
\end{tabular}

Anode outlet gas was always maintained at $\mathrm{CO}_{2}$ $66.7 \%, \mathrm{O}_{2} 33.3 \%$. This composition is equal to the theoretical value determined based on the stoichiometricratio of carbonate ion decomposition at the anode. Unexpected products were not detected in anode outlet gas. $\mathrm{CO}_{2}$ concentrationin the anode outlet gas was 6.7 times higher than that of cathode inlet gas. Further more in this case, increase of $\mathrm{O}_{2}$ concentration is also possible. The flow rate of anode outlet gas agreed with the theoretical flow rate calculated from the cell current. The results are shown in Table 4 .

\section{Table 4 The current dependence of the} flow rate of anode outlet gas.

(A)

\begin{tabular}{ccc} 
Cell current & Theoretical & Measured \\
\hline 1.24 & 13.0 & 13.0 \\
1.57 & 16.4 & 16.4 \\
1.88 & 19.6 & 19.6 \\
\hline
\end{tabular}

Therefore it was found that the current efficiency for $\mathrm{CO}_{2}$ separation was almost $100 \%$. At 150 $\mathrm{mA} / \mathrm{cm}^{2}$ of current density, approximately $1 \mathrm{~cm}^{3}$ 
$\mathrm{CO}_{2}$ separates per $1 \mathrm{~cm}^{2}$ electrode area from the cathode to the anode and these values correspond to $72 \% \mathrm{CO}_{2}$ in inlet supply gas. The cell voltage, which actually decided the efficiency, significantly depended on current density during electrolysis. This relation is shown in Fig.7.

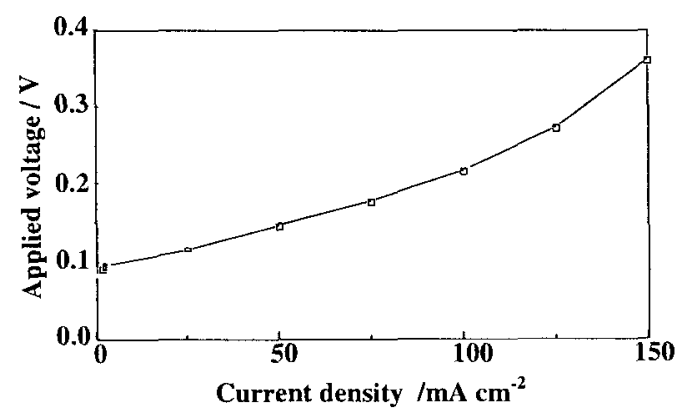

Fig.7 I-V curve of $\mathrm{CO} 2$ separation at $923 \mathrm{~K}$.

Theoretical potential difference for $\mathrm{CO}_{2}$ concentration of the cathode inlet gas was $87 \mathrm{mV}$ from equation (3). The cell voltage approached this value at the lower current density. At highcurrent density and constant inlet gas flow rate, the potential difference becomes greater since the partial pressure of $\mathrm{CO}_{2}$ in cathode gas decreases due to the consumption. The similar situation occurs in MCFC and the potential is designated as Nernst loss. With change in gaseous composition considered, theoretical potential difference can be fixed by average concentrations of cathode and anode gases. The cell voltage includes potential difference of both electrodes gases, overpotential of the electrodes reactions and internal resistance of the cell(IRloss). IR loss of the cell was obtained by internal resistance and current.Therefore overvoltage $\left(U_{p}\right)$ of reactions may be determined by subtracting potential difference (Ur) and IR loss $\left(\mathrm{U}_{\mathrm{IR}}\right)$ from total cell voltage $(\mathrm{U})$ by the equation (4):

$$
\mathrm{U}_{\mathrm{p}}=\mathrm{U} \cdot \mathrm{U}_{\mathrm{r}}-\mathrm{U}_{\mathrm{IR}}
$$

Figure 8 shows the dependence of applied voltage on current density. At $150 \mathrm{~mA} / \mathrm{cm}^{2}$ potential difference was found to be $120 \mathrm{mV}$ and the IR loss was $40 \mathrm{mV}$. From equation (4) the sum of overvoltage due to cathode and anode reactions was $200 \mathrm{mV}$, which is roughly twice the cathode overvoltage of $\mathrm{MCFC}^{6}$ ) in which oxygen reduction occurs. It thus indicates that the overvoltage of oxygen evolution (reverse of oxygen reduction) and that of oxygenreduction should be basically equal.

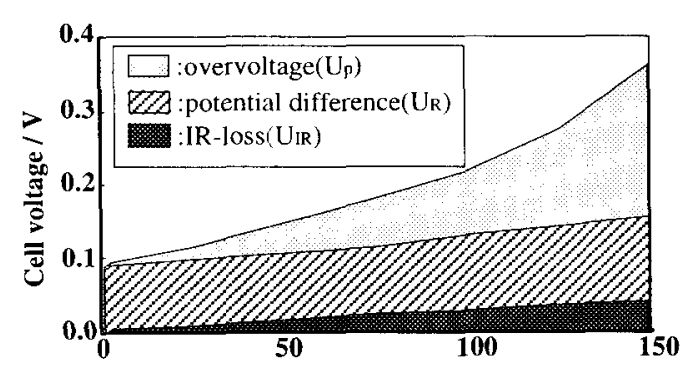

Fig. 8 Constitution of cell voltage for electrolytic $\mathrm{CO} 2$ separation at $923 \mathrm{~K}$

Because overvoltage is determined by the efficiency of electrode, it can be improved. In actual operation of $\mathrm{CO}_{2}$ concentration, the most suitable condition should be established.

\section{CONCLUSIONS}

$\mathrm{CO}_{2}$ separation and concentration were confirmed to occur in a high temperature electrolysis cell using molten carbonate and $\mathrm{NiO}$ electrodes. Current efficiency was almost $100 \%$ and stoichiometric gas composition at the anode outlet was obtained. At low current density, cell voltage was essentially the same as potential 
difference of gas composition in both electrodes. At high current density, increase in IR loss, overpotential and variation in potential were obtained.

The authors express their appreciation for the financial support of NEDO (New Energy and Industrial Technology Development Organization) of the Original Industrial Technology R\&D Promotion Program.

\section{References}

1) Handbook of Green House Effect, (Ed., H.Komiyama), p.341, 1PC Publ. Tokyo (1990).
2) A.S.Holmes, J.M.Ryan, B.C.Price, E.Styring, Hydrocarbon Processing, 61, 131(1982).

3) T.Watanabe, T.Abe, T.Shimizu, S.Sato and T.Matsuyama, CRIEP Yokosuka Research Laboratory Rep. No. W89046.

4) J.L.Weaver and J.Winnick, J.Electrochem.Soc, $130,20(1983)$.

5) T.Miyauchi, H.Uematsu, H.Hirata, T.Watanabe, K.Tanimoto and Y.Miyazaki, Energy and Resources, 11, 455 (1990).

6) Y.Mugikura, Y.Izaki, T.Watanabe, T.Abe, T.Shimizu, S.Sato and T.Matsuyama, CRIEP Yokosuka Research Laboratory Rep.No. W9302. 